\title{
Staying Afloat While Stirring the Pot: Briarpatch Magazine and the Challenge of Nonprofit Journalism
}

\author{
Patricia W. Elliott \\ University of Regina
}

\begin{abstract}
Briarpatch Magazine's four-decade history presents an enlightening case study of the value of government grants to the nonprofit and co-operative media sector, as well as the pressures these programs bring, from conflict over editorial content to unexpected funding cuts. The study reveals that a major challenge for journalism operating within the social economy is to maintain editorial independence while sustaining daily operations. Briarpatch has benefited from healthy reader support and organizational flexibility. However, this resiliency is now threatened as allied civil society networks dissipate under neoliberalism. The lessons gleaned from Briarpatch are broadly relevant to social-economy researchers and advocates, as they speak to wider questions of funder-nonprofit relationships and the role that social networks play in organizational sustainability.

\section{RÉSUMÉ}

Les quatre décennies d'histoire du magazine Briarpatch représentent une étude de cas éclairante sur la valeur des octrois gouvernementaux pour le secteur des médias coopératifs et à but non lucratif, ainsi que sur les pressions entraînées par ces programmes, allant de conflits au sujet du contenu éditorial jusqu'aux coupures budgétaires imprévues. Cette étude montre qu'un défi majeur pour le journalisme de l'économie sociale consiste à conserver son indépendance éditoriale tout en assurant son bon fonctionnement au quotidien. Briarpatch bénéficie d'un appui solide de la part de ses lecteurs et d'une bonne flexibilité organisationnelle. Cependant, cette faculté d'adaptation est actuellement menacée par un néolibéralisme qui dissipe les alliances de la société civile. Les leçons à tirer de Briarpatch sont pertinentes pour les chercheurs et partisans de l'économie sociale car elles soulèvent des questions de rapports entre investisseurs et organismes à but non lucratif et de rôles joués par les réseaux sociaux pour maintenir la durabilité organisationnelle.
\end{abstract}

Keywords / Mots clés : Third-sector media; Nonprofit media; Magazines; Grants; Fundraising; Social economy I Média du troisième secteur; Média à but non lucratif; Magazine; Octroi; Levée de fonds; Économie sociale 


\section{Elliott (2015)}

On September 7, 2013, readers of Briarpatch magazine gathered at the Artesian, a Regina concert hall, to celebrate 40 continuous years of publishing. Forty years is a major milestone, even for large-scale commercial magazines. The fact that a donor-supported, nonprofit, Saskatchewan-based publication had not only survived, but had developed a national audience, was a source of wonder even to those who helped make it happen. Speaking to the assembled celebrants that evening, Gary Robbins, a board member during the 1970s, offered an explanation, pointing to years of volunteer-run bottle drives and garage sales. $\mathrm{He}$ added:

There is a good, strong base, and I think that's really critical and really important, and why so many of the other publications that we knew of back then weren't able to continue, why those organizations morphed and changed and came and went. That's part of the lives we live in these perilous times. So it's good to see the stability of a magazine like Briarpatch ...

It was not only bottle drives that kept the presses rolling, however. In addition to advertising and newsstand sales, the magazine walked a tightrope of provincial and federal media development grants. Briarpatch's history presents an enlightening case study of the supportive value of public funding, as well as the pressures magazines face in this environment-from conflict over editorial content to unexpected funding cuts.

The lessons gleaned from Briarpatch are broadly relevant to social economy researchers and advocates, as they speak to wider questions of funder-nonprofit relationships and the role social networks play in organizational sustainability. First, however, it is important to recognize the space such media occupies within the social economy. Due to the perceived cultural dominance of commercial mass media, there is a tendency to view media outside this framework. However, there exists a rich ecology of co-operative and nonprofit media around the globe that easily falls within social economy viewpoints, as defined by John Restakis's (2006) description of a wide range of collective actions for social benefit; Marie J. Bouchard, Frank Moulaert, and Oana Ailenei's (2005) categorization of voluntary, democratic, nonprofit goods and service provision; and Charles Gide's broad conception of "all efforts made to improve the conditions of the people" (quoted in Moulaert \& Ailenei, 2005, p. 2040). As an example, community radio is an established global phenomenon, embraced in particular by rural and Indigenous communities as accessible communications platforms (Karikari, 2000; Murillo, 2008). There are some ten thousand community radio stations operating in Latin America, while African nations saw a combined 1,386 per cent increase in stations between 2000 and 2006 (Meyers, 2011). In Europe, the Community Media Forum Europe (CMFE) has mapped 521 community television stations and 2,237 community radios (CMFE, 2012). The United States is home to long-standing media co-operatives, such as the Associated Press and the St. Petersburg Times, nonprofits, such as Mother Jones, as well as numerous examples of foundation-supported journalism, ranging from ProPublica to the Public Broadcasting Service (PBS). Throughout Canada, Indigenous and northern broadcasters operate primarily within the social economy, for example the Missinipi Broadcasting Corporation (MBC), a Saskatchewan co-operative radio network, Taqramiut Nipingat Inc. (TNI), a northern charitable nonprofit radio-television network, and Aboriginal People's Television Network (APTN), a national nonprofit cable channel. Canada's publishing sector is replete with social economy enterprises, including co- 


\section{Elliott (2015)}

operative book publishers, such as Couteau Books, foundation-supported magazines, such as the Walrus, and a diverse array of nonprofit academic journals and monthly magazines, such as Briarpatch, Canadian Dimension, and This Magazine. Together, these social economy organizations work to improve media diversity and democratize Canada's communications networks, providing an alternative to heavily monopolized commercial media and underfunded public broadcasting. However, their daily travails often go unnoticed and unsupported as a distinct media sector, even among civil society allies, as noted by Robert Hackett and William Carol (2004). Meanwhile, parsimonious and politicized government funding environment have created new vulnerabilities for social economy media, as illustrated by Briarpatch's long history of involvement with provincial and federal media development support programs.

\section{GAINING AN INDEPENDENT VOICE}

Briarpatch Magazine began in August 1973 as Notes from the Briar Patch, a 10-page corner-stapled newsletter published by the Saskatoon-based Unemployed Citizens Welfare Improvement Council (UCWIC). The organization's goal was to create "a magazine for and by poor people so we could tell our own story, since we found it next to impossible to get our side represented in the mainstream media" (Fisher, 1993, p. 10). Gambling that funding would be attainable if it first established a readership, the UWIC continued to produce issues throughout the fall, distributing 500 copies monthly via the city's service agencies. The first four editions, produced on an early photocopier owned by the Saskatoon Family Service Bureau, were expensive to produce and the Thermofax paper quality was poor (as a result, no issues survive today). However, the gamble paid off; in November, the UWIC successfully obtained a \$2,500 federal grant for the newsletter from the federal Human Resources Development Agency (HRDA). Thereafter, Notes from the Briar Patch was printed on a Gestetner at the Saskatoon Community Clinic at a cost of $\$ 300$ per month. The improved printing techniques allowed circulation to expand to 2,000 copies by 1974. Co-founder Maria Fischer (1993) recalls:

Donations of dollars and fivers came in, a unionist came with a handful of stamps, letters with some quarters taped to them arrived, while other people donated packages of Gestetner paper. People from all over the province encouraged our project. (p. 10)

From the beginning, it was clear the publication intended to be more than an information sheet. Its very name represented a critical stance, being a playful pun on the last name of an unpopular local welfare officer named Brierly (Collier, 1993). The idea of media-empowered citizen engagement was described as an effort "to organize low income people in order that they might change a dehumanizing life situation ... something which the established media did not seem to be doing" (Briarpatch, 1977a, p. 1).

While the HRDA grant helped launch the publication, it was not enough to cover ongoing expenses. "We were often in a panic over whether we would be able to scrounge together enough money to prevent our phone from being cut off," UWIC president Helen Kudryk recalled (quoted in Karst, 1977, p. 6). Nonetheless, within a year Notes from the Briar Patch had an impressive distribution network and a desire to become an independent entity. At the same time, the UWIC was winding down. In 1974, the Briar Patch Society was incorporated, with a membership fee set at \$1 (Briarpatch, 1977a, p. 1). At the society's first general meeting, held February 21-22, 1974, the members agreed to produce an independent newsletter that would: act as a communications link for 


\section{Elliott (2015)}

low-income people; provide educational workshops and media access; and "evaluate, analyze, and provide constructive criticism of government programs and dealings with low income people known to the public" (Karst, 1977, p. 2). For core funding, the Briar Patch Society turned to the Saskatchewan Coalition of Anti-Poverty Organizations (SCAPO), which provided $\$ 2,500$ from its pool of federal funds. Added to this was $\$ 3,800$ from the Protestant, Lutheran, Roman Catholic and Anglican Aid Committee (PLRA, later known as PLURA, with the addition of the United Church). Although the grants were small, it was enough to carry the Briar Patch through to April 1975, when the organization received its first substantive government funding of $\$ 36,000$ from the Department of Social Services (DSS). This was supplemented by $\$ 12,700$ from the province's Employment Support Program (Karst, 1977). Consequently, government grants became central to the magazine's revenues (see Table 1).

Table 1: Early grants to the Briar Patch

\begin{tabular}{|l|l|l|l|}
\hline Year & Agency & Type & Amount \\
\hline 1973 & $\begin{array}{l}\text { Human Resources Development Agency } \\
\text { (HRDA) }\end{array}$ & Federal & $\$ 2,500$ \\
\hline 1974 & $\begin{array}{l}\text { Sask. Coalition of Anti-Poverty } \\
\text { Organizations (SCAPO) }\end{array}$ & CBO & $\$ 2,500$ \\
\hline & $\begin{array}{l}\text { Protestant, Lutheran, Roman Catholic and } \\
\text { Anglican Aid Committee (PLRA) }\end{array}$ & CBO & $\$ 3,800$ \\
\hline 1975 & PLRA & CBO & $\$ 3,800$ \\
\hline & Employment Support Program & Provincial & $\$ 12,700$ \\
\hline & Dept. of Social Services (DSS) & Provincial & $\$ 36,000$ \\
\hline 1976 & DSS & Provincial & $\$ 36,142$ \\
\hline 1977 & DSS & Provincial & $\$ 51,376$ \\
\hline & Canada Manpower & Federal & $\$ 1,236$ \\
\hline 1978 & DSS & Provincial & $\$ 54,431$ \\
\hline
\end{tabular}

Sources: Karst, 1977; Briarpatch annual financial statements, 1976-1978

However, even after the receipt of the DSS funding, the continuing need and desire for donor involvement was evident in a May 1975 appeal to readers:

The Briar Patch typewriter has broken down and we are in desperate need of a replacement. Any offers and suggestions from our readers is much appreciated. (Pottruff, 1975, p. 1)

Thus, while provincial funding was a boon to operating expenses, the idea of pitching in remained central in the magazine's communications with its readers and supporters. The Briar Patch Society successfully pursued 


\title{
Elliott (2015)
}

federal charitable status in 1975, allowing the society to issue tax receipts in exchange for donations (Pottruff, 1975).

The issue for May 1975 opened with a poem that underscored the Briar Patch's connection to movements for social change:

\author{
We are all getting wise \\ We have to organize \\ We all just must pitch in \\ A better world to win \\ A few have a ball \\ Many nothing at all \\ The welfare of one \\ Must be the welfare of all.
}

The edition's 22 stories conveyed a mixture of information, advocacy, and straight-up news reporting. Also included was a letter from the provincial government's Vocational Training Program that disputed a previously published editorial, revealing some early tensions between the information needs of government and the independent spirit of the magazine. For the moment, though, Briar Patch staff remained confident in the support they were receiving from a socially minded New Democrat Party (NDP) government. A 1975 letter from a DSS supervisor noted, "Certainly in the province of Saskatchewan, where the number of communication avenues are few and generally polarized, this paper has been of immense value to many people in the province" (Reiter, 1975, Sept. 26).

In 1976, the Briar Patch's main office shifted to Regina, to be closer to the province's political centre, and the enterprise began to take on the feel of a newsroom rather than an antipoverty service organization. At Briar Patch's second annual meeting in April 1976, members significantly added workers and Indigenous people to its stated mandate of supporting low-income people. This reflected the beginning of a longstanding association with the labour movement. That year the Saskatchewan Federation of Labour (SFL) agreed to mail 500 copies to its affiliates, a significant contribution to the cost of distribution (Briar Patch staff meeting minutes, July 20, 1976). The expanded mandate statement also signalled increased interest in coverage of northern and Aboriginal issues. At the meeting, members restated that, in addition to producing a newsletter, the society aimed for a more just society (Karst, 1977).

At this point, the province appeared satisfied with the magazine's direction and growing audience (see Table 2). A letter from social services minister Herman Rolfes wishes the Briar Patch Society "every success in the continued publication of the monthly newspaper, [which provides] a valuable service to the economically disadvantaged people in our community" (Herman H. Rolfes letter to M. Fisher, April 26, 1976), accompanied a grant of $\$ 36,053$ for 1976-1977. The government's expectations of the magazine were clarified in its 1977 funding agreement, which outlined the parameters of a $\$ 39,000$ grant for the coming year. According to the terms of reference, the role of the Briar Patch was to "report events by and of interest 


\section{Elliott (2015)}

to disadvantaged people around the Province of Saskatchewan" as well as to "publish letters, articles and reports that will foster the expression of concerns and communication about disadvantaged people" (Saskatchewan. Dept. of Social Services, 1977, p. 1).

Table 2: Subscription growth, 1976-1977

\begin{tabular}{|l|c|c|c|c|}
\hline Year & Saskatchewan & Out of Province & International & Total \\
\hline April 1976 & 251 & 41 & 5 & 297 \\
\hline February 1977 & 494 & 84 & 23 & 601 \\
\hline
\end{tabular}

Source: Karst, 1977

The government's sense of the magazine's purpose was narrower than the mandate set out by Briar Patch members, who at their founding annual meeting called for "factual and relevant information to the public," without limiting the topic areas to antipoverty issues or the audience to impoverished people (Briar Patch Society, minutes of the first annual meeting, 1974). The disparity of aims was observed by Grant Karst (1977):

The department is financially supporting an organization whose mandate includes critically analysing service delivery and exposing inadequacies and abuses within that department. The Briar Patch is accountable to its target population. (p. 10)

The movement away from a localized volunteer-produced newsletter to an independent, staffed provincial magazine created internal debates over ensuring continued public input. One outcome was a restructuring initiative that established local editorial collectives around the province with the goal of "truly becoming a paper with a provincial scope" (Minutes of the editorial committee, September 19, 1976). In January 1978, the nonprofit society reincorporated as Briarpatch, Inc., and changed the publication's title to a single word, Briarpatch. Board and staff sharpened the focus on independent journalism, joining the Canadian Periodical Publishers Association and attending the founding conference of the Canadian Investigative Journalism Association (Gilmour, 1993). Briarpatch's primary raison d'être was by now well grounded within common definitions of accountability journalism, i.e., carrying out investigations and holding establishment structures to account for policy decisions. For example, Briarpatch printed critical coverage of the expansion of uranium mining in the north under the NDP, as well as provincial cutbacks to daycare and legal aid. It perhaps should come as no surprise then, that Briarpatch's funding relationship with the province was endangered in the back rooms of power.

There were few hints of what was to come. Buoyed by generously worded letters of support from DSS officials, society members assumed the relationship remained harmonious. In its 1977 submission, Briarpatch asked for and received additional funding to hire a fifth staff person (Briar Patch Society, 1977a, May 3). Dependency on provincial funding had by now grown to a very high level. The DSS grant for 1977-78 amounted to $\$ 51,376$, almost the entirety of the magazine's $\$ 58,628$ in revenues (see Figure 1). Donations, in comparison, were $\$ 142$, or less than 1 percent of revenues. 
Elliott (2015)

Figure 1: Briarpatch revenues, 1977-1978

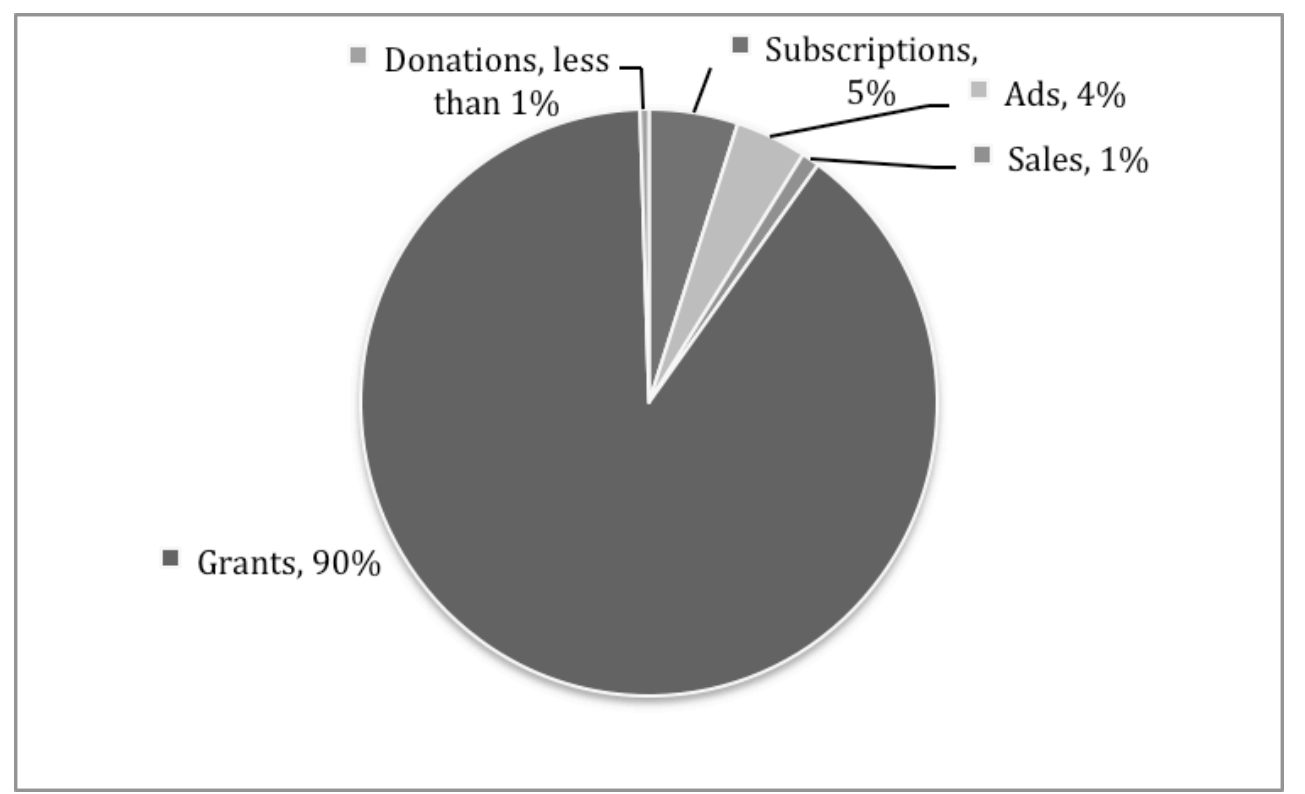

Source: Briar Patch Society annual financial statement, April 1, 1977 to March 31, 1978

Clearly, this was a balance that left the magazine vulnerable and, indeed, the society worked to diversify its revenue by establishing a typesetting business called First Impressions. First Impressions was almost immediately successful, grossing $\$ 9,514$ in its first year of operation. Additionally, donations were modestly boosted in 1978-79 to $\$ 1,505$ (Briarpatch annual financial statement, 1978-1979). Although the contributions of First Impressions and donors were relatively small, the seeds planted would prove to be crucial to the magazine's survival in the coming year.

In December 1978, Briarpatch, Inc. submitted a $\$ 60,000$ budget for 1979-1980. A few days later, staff received a tip from a Canadian Broadcasting Corporation (CBC) source that funding was about to be refused (Briarpatch president's report on funding, 1979). A follow-up call to the DSS in early January 1979 resulted in reassurances that the magazine was doing a good job and there was no reason to worry about future funding. But then, at an April 12, 1979, meeting, the DSS's new head of community services informed the nonprofit that it would be given six months of funding, during which time it should seek a new revenue source. A report to Briarpatch's board from its president stated, "The reasons for this decision were basically that the department had changed its priorities and that Briarpatch was not providing direct accountable services" (Briarpatch president's report on funding, 1979, p. 2). Indeed, in the wider economic picture, the DSS faced a potential loss of $\$ 6.5$ million in anticipated federal transfers, after a new federal-provincial financing agreement had died on the order paper. In preparation for the coming budget year, officials sought 3 percent cuts throughout the department (Brettle, 1979c). 


\section{Elliott (2015)}

Finally aware of the lay of the land, the magazine's board met to discuss measures to have in place within six months, including increased ad sales, applying for a loan, and approaching civil society organizations for support. Then, on April 19, 1979, the Leader-Post and the StarPhoenix reported Briarpatch's funding had been entirely cut as of April 1 (Brettle, 1979b). In the article, Minister Rolfes stated the magazine no longer addressed poverty issues and therefore was not a candidate for DSS funds. Staff member Rici Liknaisky responded, "When they say we are not covering poor people's issues they mean we are covering poor people's issues that are embarrassing to them" (quoted in Brettle, 1979b, p. 18). It was not until April 26 that the magazine received official notice of a cut retroactive to the beginning of the month, in the form of a letter from the minister (Briarpatch president's report on funding, 1979, p. 2).

Although the cut was framed as a purely economic measure, "many suspected the real reason was the magazine's vigourous anti-nuclear stance" (Powell, 1993, p. 15). Staff members conducted an inventory of stories and found antipoverty coverage remained a substantial portion of the magazine's coverage; they concluded articles critical of uranium mining and social service cutbacks were the likely red flags (Gilmour, 1993). This sentiment appeared to be backed up by an anonymous DSS official, who stated in the Leader-Post, "How can I go to cabinet and ask them to approve funding for a magazine that is critical of uranium development?" (quoted in Brettle, 1979d, p. 53). A commentary in an NDP-affiliated newspaper called the Commonwealth, added the DSS would be "ill advised" to support an independent, critical news magazine because "of what the opposition could do with in the legislature" (Robertson, 1979).

Without the promised six-month grace period, the magazine was thrown into immediate crisis. The May edition on the theme of disabled people's issues was already on its way to the press, budgeted for on the premise of a sixmonth transitional grant (Brettle, 1979b, p. 18). Half the staff members were laid off and the June 1979 issue was cancelled (Powell, 1993). Attempts to find replacement grants, including applications to the Donner Canadian Foundation and the Sask Sport Trust, were unsuccessful; neither agency included media undertakings among eligible projects (C. MacKinnon correspondence with C.V. Powell, April 25, 1980; D. Fry correspondence to N.L. Burton, July 3, 1979). Nonetheless, "we're not going to pack up and go home," board member Gary Robbins vowed (quoted in Brettle, 1979b, p.18). The magazine turned to revenue seeds it had fortuitously planted the previous year. The typesetting business First Impressions provided a lifeline, grossing \$17,892.81 in 1979-1980. The board launched a successful emergency fundraising campaign that raised nearly $\$ 10,000$ in one-time and sustaining monthly donations before the year was out (Briarpatch annual financial statement, 1979-1980). The magazine also held its first $\$ 20$-a-plate dinner-no small sum at the time-raising $\$ 3,400$ in a single evening (Manz, 1993). These activities set the basic template for Briarpatch's future sustainability; by the end of fiscal year 1980-81, the revenue picture was substantially transformed, with nearly $\$ 20,000$ raised in donations and subscriptions, and First Impressions sales of $\$ 12,974.93$ netting $\$ 5,438.49$ for the magazine (see Figure 2). Thus Briarpatch managed to pay its bills (primarily salaries and printing) and realize a modest surplus of $\$ 1,696.56$ (annual financial statement, 1980-81), prompting the Leader-Post to declare "a major victory" for the magazine (Leader-Post, 1981, p. A4). 
Elliott (2015)

Figure 2: Briarpatch revenues, 1980-1981

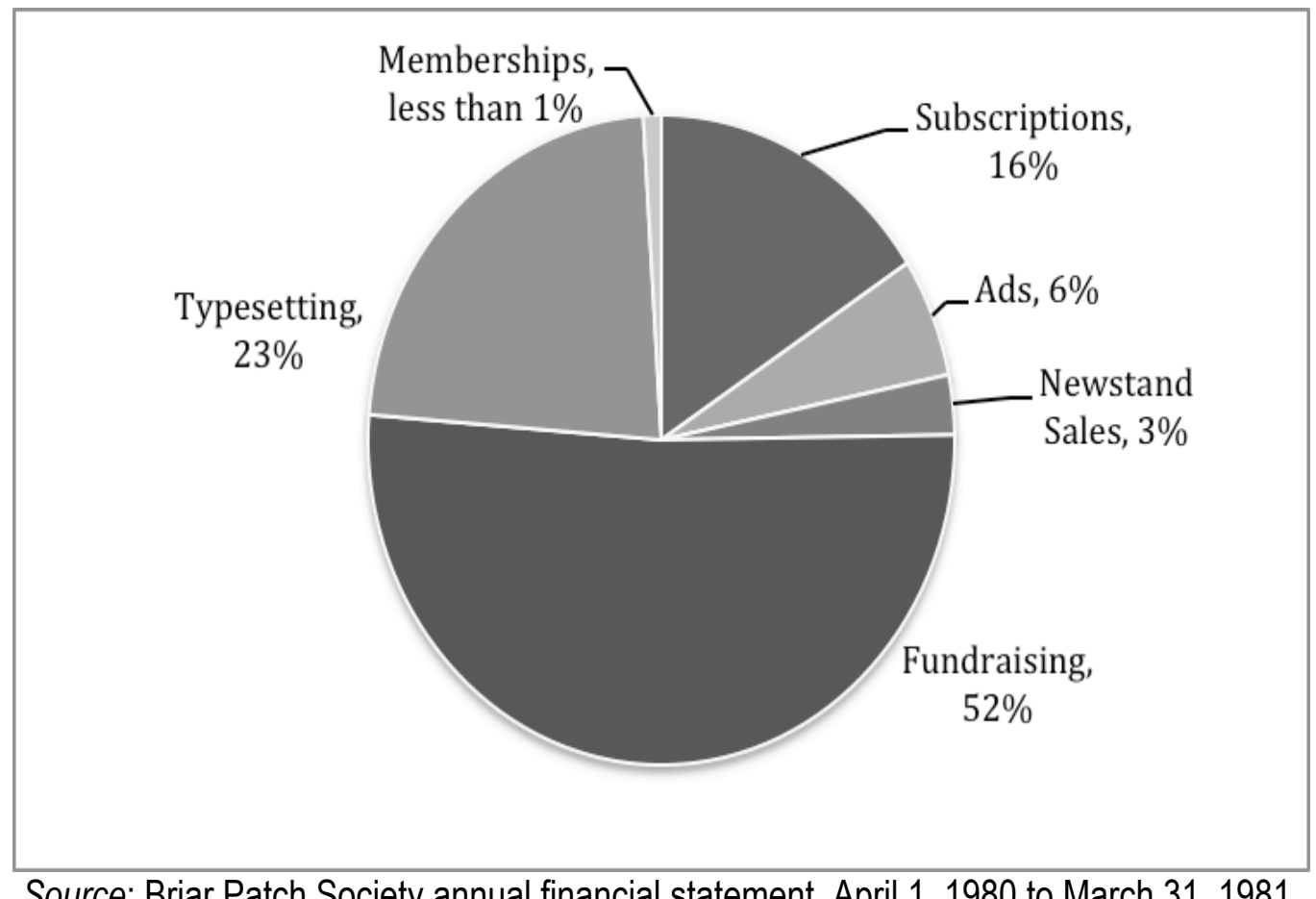

Source: Briar Patch Society annual financial statement, April 1, 1980 to March 31, 1981.

\section{ACCOUNTABILITY JOURNALISM: REWARDS AND RISKS}

How a magazine could increase reader support from a few hundred dollars to nearly $\$ 20,000$ within two years may be attributable to this observation by Beth Smillie (1993): "Briarpatch developed into something much more than a low-budget magazine. It became a social movement of its own" (p. 17). As a primarily reader-supported magazine, Briarpatch continued to sharpen its journalistic teeth in the 1980s, providing critical analysis of environmental and labour policies during the NDP government's last years of power (Powell, 1993). Following the 1982 election of Grant Devine's Conservative Party, Briarpatch became a locus of critique and investigation in the realm of provincial politics, digging deep into business links between Conservative Party supporters and the spoils of privatization (Paavo, 1993). During this time period the magazine received several awards and honourable mentions from journalism organizations, however, it also attracted less favourable attention. Rightwing commentators, unfamiliar with Briarpatch's thorny NDP relationship, assumed the coverage was partisan, and voiced complaints about the magazine's charitable status:

Out of power, socialists must find ways to rally the troops. ... Brierpatch [sic] plays a vital role in their survival strategy. ... Somehow Brierpatch [sic] contrived to get it registered as a charitable foundation so left-wingers across the country can get tax write-offs on their donations, leaving taxpayers to subsidize its proselytizing work. (Baron \& Jackson, 1991, p. 18) 


\section{Elliott (2015)}

In 1987 Revenue Canada revoked Briarpatch's status, stating the magazine "is not only concerned with the issues affecting low income individuals and organizations but also deals with many topics (e.g. international events, native education, strikes at industrial plants, shopping for home mortgages, the health care system and apartheid) in a manner that is not considered to be charitable at common law" (quoted in Paavo, 1993, p. 20).

Noting that overtly ideological organizations, such as the Canadian Anti-Communism Crusade, held charitable status, the board launched an energy-sucking and ultimately fruitless challenge to the ruling. In the end, however, it appeared tax receipts mattered little to Briarpatch donors, whose contributions climbed to $\$ 29,356.51$ in 1987-1988, outstripping subscription and advertising sales, and reached $\$ 31,693.33$ by 1990 1991 (Briarpatch annual financial statements, 1988 and 1991). The magazine also regained a foothold in the grant world, primarily in the form of job creation subsidies, as well as international-themed project funding via Partnership Africa Canada (PAC) and Canadian International Development Agency (CIDA)-sponsored development education centres. However, these grants never amounted to more than 25 percent of total revenues and disappeared entirely for nine years after 1995-1996, a year that saw massive federal cuts to social spending, including a 100 percent cut to development education centres across Canada (Canadian Council for International Co-operation, 1995) (see Figure 3).

Figure 3: Briarpatch major revenue streams, 1976 to 2009

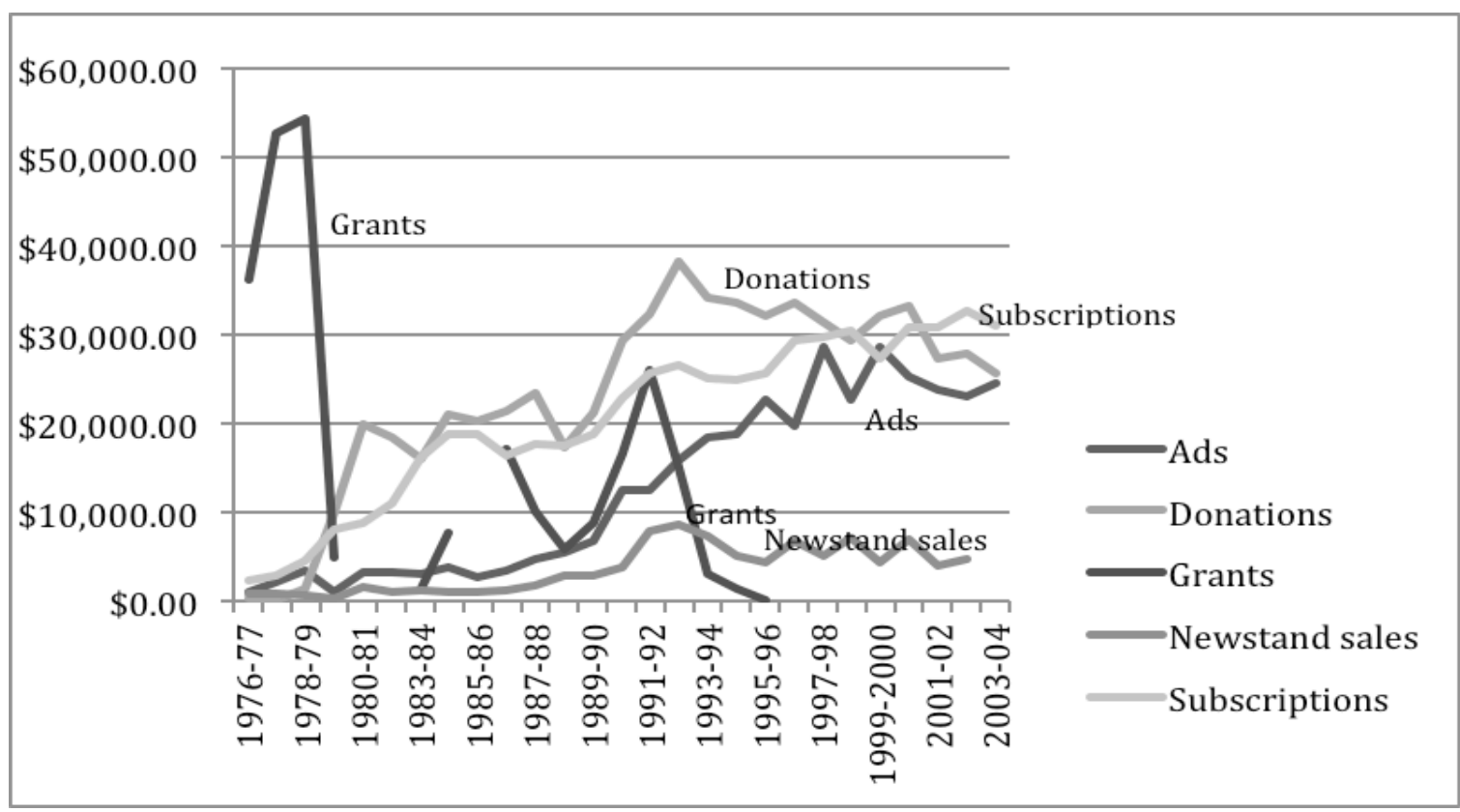

Source: Briarpatch annual financial statements, 1979 to 2010 


\section{Elliott (2015)}

Following the 1991 election of an NDP government, donations and sales flatlined, perhaps reflecting a lessening sense of urgency among left-leaning readers (Warnock, 1993). As well, the diversity of supportive Saskatchewan-based social movement organizations declined in the 1990s, a decade when arts, women's, and international development organizations saw funding dwindle. While there is no quantifiable data connecting organizational loss to stagnating revenues, it stands to reason that each group that closed its Saskatchewan office represented one less platform for reaching new subscribers and donors. One area where the phenomenon of organizational loss can be quantified is in the diversity of Briarpatch's advertising revenues (see Figures 4 and 5 for comparison).

Figure 4: Briarpatch advertising revenue sources, 1986

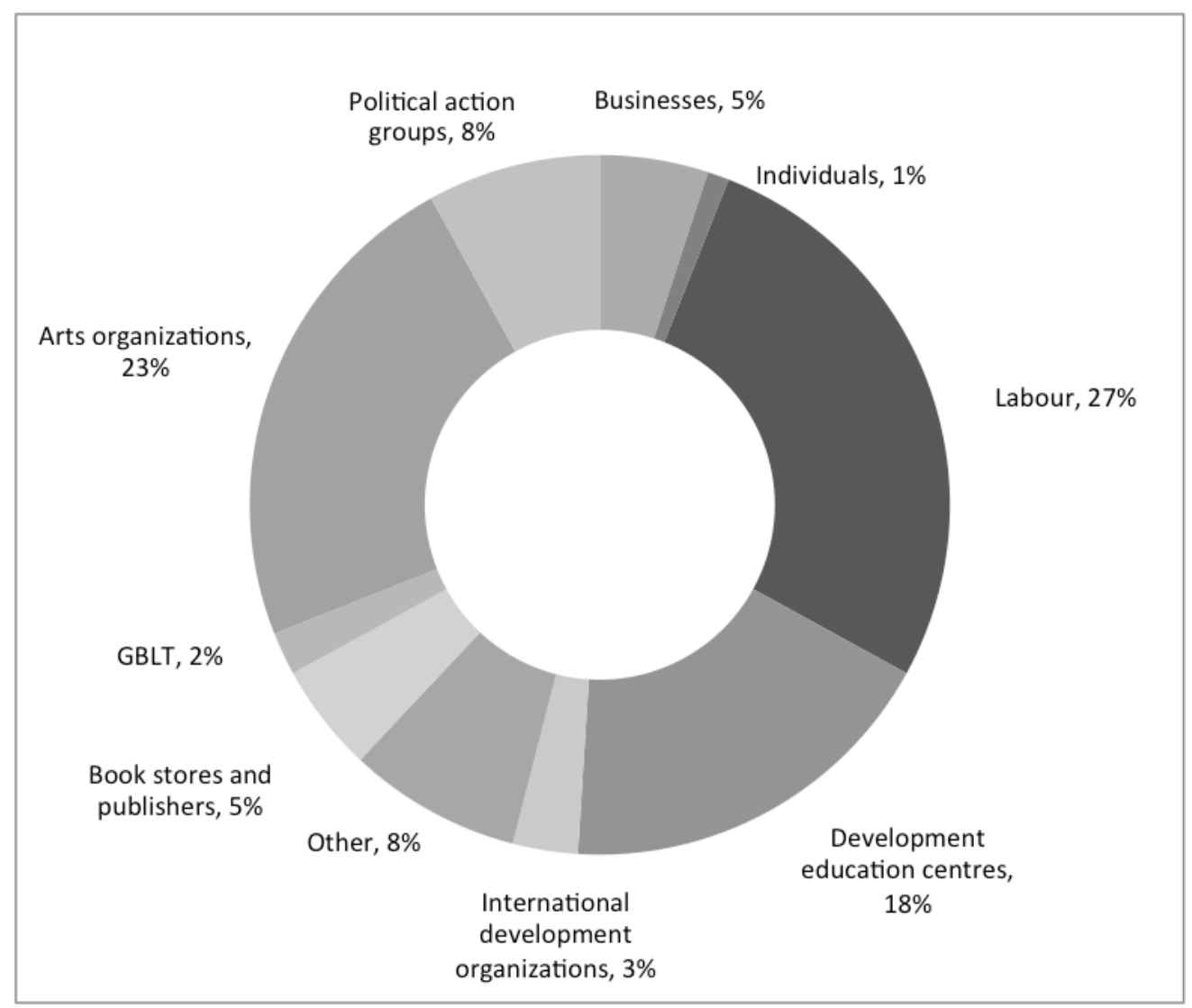

Source: Briarpatch advertising invoice log, 1986 calendar year 
Elliott (2015)

Figure 5: Briarpatch advertising revenues, 2000

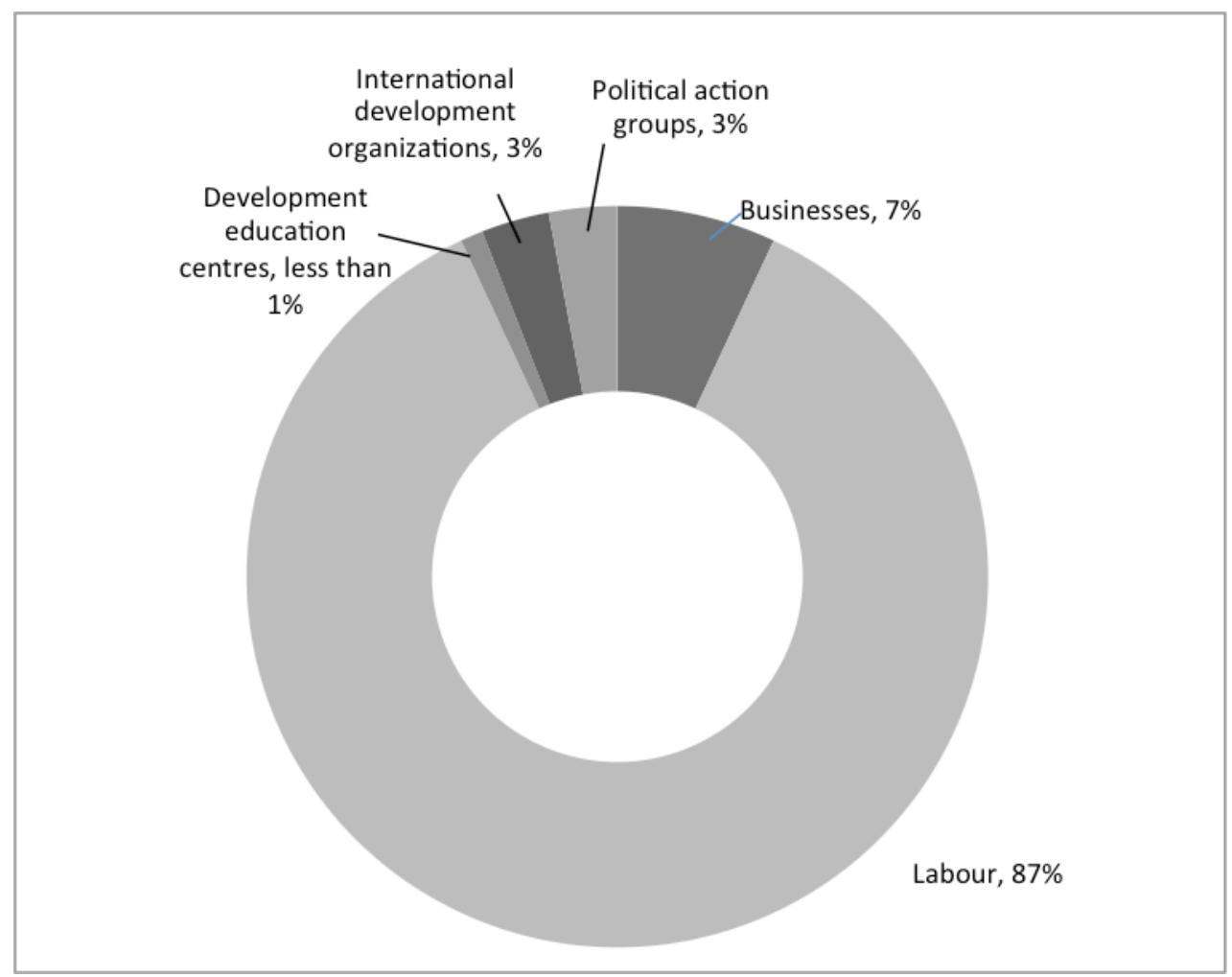

Source: Briarpatch advertising invoice log, 2000 calendar year

By 2002-2003, in addition to putting out the magazine, two staff members were left to coordinate more than $\$ 23,000$ in fundraising, along with managing $\$ 37,508$ in magazine sales and $\$ 23,108$ in ad sales (annual financial statement, 2002-2003). In contrast, in 1977 four staff members were responsible for selling some $\$ 2,000$ in advertising and managing approximately $\$ 3,700$ in magazine sales, with little responsibility for additional fundraising (annual financial statement, 1977-1978). Further, stagnating revenues thwarted the board's desire to pay its writers, which was considered key to expanding the magazine's investigative content. As observed by Valerie Zink, editor-publisher from 2010 to 2013, "[i]t's quite evident that the investigative stories we do publish are the ones that are most widely read and most well received, and there's a real hunger for that" (personal communication, March 27, 2012). These pressures pushed Briarpatch to look beyond Saskatchewan's borders for assistance (David O. Mitchell, past Briarpatch publisher-editor, personal communication, June 12, 2012).

\section{CALLING THE TUNE: FEDERAL GRANTS}

In 2003, editor Debra Brin drafted a three-year $\$ 121,581$ proposal to the Canada Magazine Fund (CMF), administered by the Department of Canadian Heritage. The proposal included a full-on marketing campaign, including billboards, radio ads, bus ads, media kits, a portable display, logo design, staff car decals, and new 


\section{Elliott (2015)}

building signage. The stated goal was to increase circulation by 10 percent annually, reaching a 30 percent increase by the end of year three. In discussions with CMF program officers over the next several months, the plan was honed down to a single-year $\$ 28,805$ request, primarily for staff training and market consultations; in early 2004, the magazine received word that $\$ 26,295$ was approved (Judith Larocque letter to D. Brin, January 26, 2004). Staff training was a welcome investment. In an application to attend a Canadian Magazine Publishers Association training course, Brin wrote, "I had no training or background in journalism before I took this job so I am basically learning by surviving one disaster or close call after another" (Magazines Canada School for Professional Publishing (MCSPP) application, February 10, 2004). This and other national training programs, covering topics such as circulation management, marketing, and other aspects of the business of publishing, were appreciated and put into practice by staff (D. Mitchell, personal communication, June 12, 2012). Of perhaps greater impact, however, was the manner in which the project led Briarpatch's staff and board to reconsider their understanding of the publication's core audience and, therefore, its editorial focus.

In a business plan drafted in preparation for the 2003 funding application, Briarpatch positioned itself as a provincial magazine that featured a majority of articles written by Saskatchewan writers who offered "a view of social justice issues from a perspective unique to Saskatchewan" (Briarpatch business plan, 2003). Once the project was funded and underway, however, a different picture emerged. Within the context of a market study, Briarpatch's board and staff undertook a structured review of its 1,100-member subscription base. The review revealed that the majority of Briarpatch subscribers lived outside Saskatchewan, with more than half in $\mathrm{BC}$ and Ontario (Briarpatch summary data report, n.d; D. Mitchell, personal communication, June 12, 2012). Accordingly, the magazine transformed its editorial focus from that of a provincial magazine to a magazine aimed at a national and international audience.

Briarpatch successfully applied for business development funding in subsequent years, receiving a total of \$116,983 between 2005 and 2008 (Canada. Department of Canadian Heritage, 2004; 2005; 2006; 2007; 2008; 2008). Direct mail ad campaigns carried out with project funding assistance realized a 31 percent increase in paid circulation by March 2006, meeting and slightly exceeding the campaign's original stated goal of a 30 percent increase within three years (staff report, grant history, 2006). This was followed by a 29 percent increase in a single year, 2007-2008 (final report to CMF, June 23, 2008). With increased subscription revenues, the magazine fulfilled its longstanding goal of paying writers, starting with $\$ 491$ paid out in freelance fees in 2006, followed by $\$ 2,107$ in 2007 and $\$ 5,040$ in 2008 (Briarpatch financial statements, 2006-2009). Other CMF-supported accomplishments included launching a revamped website in 2005 and updated subscription management and publishing software. In summary, the support of federal media development funds helped lift Briarpatch from a stagnating provincial publication to a national magazine with paid writers, trained staff, and an ever-widening base of subscribers. However, this came at a price. First, the grant application and reporting processes consumed increasing amounts of staff time to meet the government's need for detailed information, as illustrated by this query:

Who will be responsible for converting new data to new fulfillment software? (if other than regular staff, please provide c.v.) .... What is the content of the brochure? Format? Is there a detachable subscription portion? (N. Jordan email to D. Brin, November 25, 2004) 


\section{Elliott (2015)}

These information needs did not begin and end with the annual application but continued throughout the year. For example, a decision to send the editor to an Independent Press Association (IPA) conference rather than to a labour convention generated five email exchanges with Ottawa, and required recalculation of the in-kind budget line, along with a detailed written description of what knowledge would be obtained at the IPA conference and how it would be disseminated (interim report email correspondence, Nicole Jordan to Chelsea. Looysen, February 9-23, 2006).

Second, the CMF grants once again increased the magazine's dependence on external government funds that were beyond the magazine's control, echoing a picture that had led to crisis three decades earlier (see Figure 6). From this perspective, the magazine's situation could be considered more precarious, not less precarious.

Figure 6: Briarpatch revenues, 2008-2009

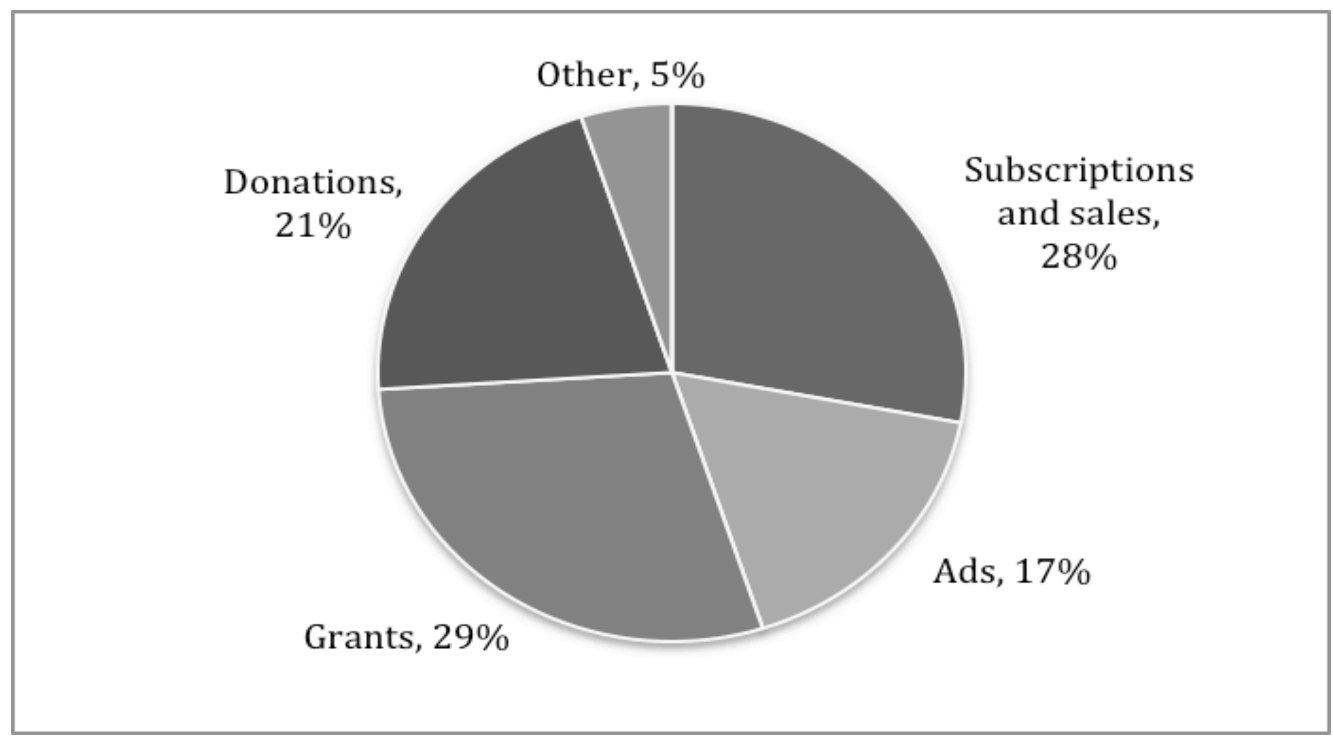

Source: Annual financial statement, 2008-2009

This vulnerability was made clear following the election of a Conservative-led federal government in 2007. Briarpatch staff developed a relatively modest project plan for 2008-2009, requesting $\$ 25,000$ for a direct mail subscription campaign and funds to hire an advertising consultant to negotiate long-term advertising agreements (project funding application, 2008). For the first time, the application generated hard questions from CMF staff about the magazine's evolution since its first grant, noting, for example, a lack of growth in profits. The publisher responded that:

given we are a nonprofit magazine that is currently comfortably in the black, this is not a major concern for us at this time; nor, I would argue, should it be used as an argument that we have failed to evolve. As a nonprofit our goal is not to run a large surplus each year, but to reinvest 


\section{Elliott (2015)}

the revenue increases we've enjoyed in recent years into the operations of the magazine-and this we have done. (Shayna Stock, publisher, Briarpatch, email to Nicole Jordan, project officer, Canada Magazine Fund, August 14, 2008)

In late September, CMF staff responded that the magazine's "justification in support of the project was well received by the committee" and a recommendation was going forward to approve the full amount of the project, scheduled to begin December 1, 2008 (N. Jordan email to S. Stock \& D. Mitchell, September 26, 2008). This was followed by a long period of silence. In February 2009, serious concerns began to develop in the Briarpatch office about how to manage proposed activities that were still un-funded. Email inquiries to CMF staff shed little light on the situation (email correspondence, February 2-24, 2009). However, internal CMF correspondence reveals staff was aware the project application was caught on the minister's desk (MINO):

Just a reminder. We still have an SBDMP [Support for Business Development for Magazine Publishers] project in MINO: Briarpatch. It was sent December 5, we still don't have a decision, and it shows 'holding MINO.' We have followed up constantly with G\&C Secretariat (Chantal Paré) who basically confirms it's still there. We're not sure how to proceed and what we can say to the client. (Jeanne Lahaie-Torres, manager, SBDMP, Canada Magazine Fund email to Scott Shortliffe, director, Periodical Publishing Policy and Programs (PPPP) March 3, 2009)

A response from the fund's program director stated no progress had been made and suggested taking the issue to higher levels. A series of subsequent emails, presumably taking up this suggestion, are too heavily redacted to discern the nature of discussions. However, the frequency and tone of email inquiries from staff suggests that difficulty gaining a ministerial signature for an approved project was unusual. On May 6, an email informed program staff, "fyi-we can consider briarpatch rejected," adding that the client should be informed of the "ministerial decision" via standard rejection letter (Scott Shortliffe, director, Periodical Publishing Policy and Programs (PPPP), to Jeanne Lahaie-Torres, manager, SBDMP, Canada Magazine Fund, May 6, 2009). A staff member's request for clarification on why the recommendation was rejected was answered with "come and see me if you wish to discuss" (Scott Shortliffe, director, Periodical Publishing Policy and Programs (PPPP) to Marija Renic, project officer, Canada Magazine Fund, May 6, 2009). Whatever may have been discussed, the reason conveyed to Briarpatch employed a rejection letter template developed in April 2009:

Your proposal was reviewed in light of the government's ongoing objective to fund projects that provide measurable, tangible results which contribute to Program objectives and meet the needs of Canadians. It is within this context that I regret to inform you, on behalf of the Honourable James Moore, Minister of the Department of Canadian Heritage, that your application has not been approved. (S. Shortliffe letter to S. Stock, May 6, 2009)

The internal departmental rejection report stated, "File rejected by Minister Moore. Instructions given by the Chief of Staff at the May 4 Look Ahead Meeting of May 4, 2009 to inform client of the decision" (Canadian Heritage Grants and Contributions rejection report, July 31, 2009). On May 21, CMF program staff filed a "request for change of fund commitment" from $\$ 25,000$ to zero, indicating the project had already been in the 


\section{Elliott (2015)}

budget pipeline before failing to gain the minister's signature. In a telephone conversation with a staff member, editor Dave Mitchell asked if the rejection was related to the magazine's political content; the response indicates staff members themselves had few solid answers about the new funding environment:

I indicated that as far as I know there was no [political] issue - we weren't aware of any. [He] wanted tips concerning reapplying to [the] program. I told him I didn't really have any — but that applicants showing significant gains in their financial results were more likely to be approved. (unknown author, CMF hand notes of telephone conversation with D. Mitchell, May 7, 2009)

The latter sentence indicated that larger commercial magazines were likely to fare better than nonprofit and small circulation magazines. Nonetheless, the conversation was reassuring enough for Briarpatch staff to undertake work on a new funding application for 2009-10, a $\$ 33,545$ request for online marketing and advertising development. This application was sidelined in the midst of a program revamp that included the ending of the SBDSMP grant program (Briarpatch, Inc., SBDSMP funding application, August 18, 2009; Canadian Heritage grants and contributions rejection report, Dec. 3, 2009).

Undeterred, Briarpatch submitted an application to a new Business Innovations for Print Periodicals (BIPP) program in September 2010, again focusing on Web development and marketing (Briarpatch Business Innovations application, September 27, 2010). This time there appeared to be nothing standing in the way of approval. Correspondence between submitting and finalizing the application shows a period of minor tinkering over how expenses were expressed in various budget lines of the $\$ 22,453$ request, while the overall project concept itself appeared to have the support of the new Canada Periodical Fund (CPF). An internal funding commitment request was formatted and finalized on December 3,2010, and submitted to the Grants and Contributions Management Information System (S. Belisle email to M. Legros, December 3, 2010). A standard response notification acknowledged the amount was entered in the system, and that any communication of approval to the client must await the minister's signature (GCMIS notification, December 22, 2012). Then, in a replay of Briarpatch's earlier experience, a long silence followed. Finally, on February 9, 2011, program staff received an internal notice of rejection from the minister's office, signed by Minister James Moore, with the rationale recorded simply as, "I do not approve this grant" (ministerial decision document, February 9, 2011). A standard rejection letter to Briarpatch stating the fund was seeking measurable results for program objectives followed. Once again, Briarpatch followed up with a phone inquiry seeking future guidance, this time from publisher Shayna Stock. The program director noted:

Talked to her. Very disappointed, asked if there was an appeal process, asked what more they could do in terms of measurable results (as this is their third rejection). I had to say that there is no appeal process, and that as these are judgement calls, there is no specific threshold for measurable results. (Scott Shortliffe, director, Periodical Publishing Policy and Programs (PPPP), Canadian Heritage email to Jeanne Lahaie-Torres, manager, Support for Business Development for Magazine Publishers, Canada Magazine Fund, February 22, 2011) 


\section{Elliott (2015)}

Dissatisfied with the response, Stock emailed the project officer assigned to Briarpatch for further insight. Noting that the officer had indicated the project was "a solid one" and seemed confident in its approval, Stock asked, "Do you have any insights whatsoever what happened to our application after it left your hands, and why it might have been denied?" (S. Stock email to J. Lahaie-Torres, February 22, 2011). This prompted an internal request from the project officer seeking clarification of the response already given, to which the director replied:

since this was not an eligibility question, but a judgment call, there is no guidance we can provide on future projects at this time. ... I realize this is frustrating for the applicant, but there is no more information we can offer on the decision. (Scott Shortliffe, director, Periodical Publishing Policy and Programs (PPPP) email to Jeanne Lahaie-Torres, manager, Support for Business Development for Magazine Publishers (SSBDMP), Canada Magazine Fund, February 24, 2011)

Thus, after three years of intensive, time-consuming work on project applications, Briarpatch walked away suddenly bereft of nearly 20 percent of its planned budget, and a nagging suspicion that politics had come to bear on the final decision. Once again, Briarpatch turned to its readers to help fill the gap. "Part of the response to the denial of funding was to really push the monthly donations and make up the shortfall," recalls former editor Mitchell (personal communication, June 12, 2012). This was not easy in a new political landscape where "everybody's having to jump back at the same time, from institutional funding to individual support" (personal communication, June 12, 2012). And although readers responded generously, there would be no cost recovery for lost staff time and three years of budget instability.

Another cost was local accountability journalism. The "federal funding years" had pulled Briarpatch into a paradigm that required continual market expansion, drawing the magazine toward national and international audiences. Previously, Briarpatch had a strong record of covering rural and northern Saskatchewan policy issues, and policies affecting low-income urban dwellers. These stories no longer had space in the magazine, unless filtered through a national lens (D. Mitchell, personal communication, June 12, 2013). This is not to assume stories written for a national audience did not have a local dimension or local impact. Local actions, for example a First Nations blockade or a new food co-operative, were frequently featured and linked to larger national or international movements. As well, there was a strong sense among the editors that national and international stories were ultimately aimed at inspiring and informing civic participation at the local level (Valerie Zink, past editor-publisher, Briarpatch, personal communication, March 27, 2012). In December 2008, an entire issue was dedicated to Saskatchewan, in the context of explaining and critiquing its changing economy to the rest of the country. However, this did not assuage a desire among Saskatchewan readers for articles specifically examining the provincial scene.

Much of the push was around northern and environmental issues, such as tar sands development, as well as the policies of the Saskatchewan Party, established in 1997 and elected to power in 2007. Briarpatch's board recognized that failure to respond to the local base could affect the magazine's future sustainability. While the magazine's market was national, its core supporters, the people who collected swim-a-thon pledges and volunteered for bottle drives, were Saskatchewan residents (D. Mitchell, personal communication, June 12, 2013). 


\section{Elliott (2015)}

In response, the Briarpatch board began discussing the idea of establishing a new provincial publication that would share resources with the magazine. Its goal would be to re-introduce the style of independent investigative journalism that defined the Briarpatch's heyday of muck-raking journalism under the Grant Devine Conservative government (D. Mitchell, personal communication, June 12, 2012). A Briarpatch reader survey confirmed a desire for investigative work; 70 percent of respondents stated they wanted to read more investigative journalism, compared to 38 percent requesting more theory and analysis (survey summary report to Briarpatch AGM, 2007). On the surface, it seemed conditions were ripe: a right-wing party was in power provincially, and topics like privatization and uranium development, which had been popular with readers in the 1980s, were back in the limelight. The launch of the Sasquatch would soon reveal, however, that the landscape had shifted in other ways, leaving less space for a nonprofit publication to grow roots and thrive. In particular, a push for labour supportconsidered a key fundraising strategy_fell flat after some initial uptake. "There was sort of polite tolerance ... I got the sense that ... it wasn't really a priority," recalls Mitchell (personal communication, June 22, 2012). The publication launch had dovetailed with a general decline in social unionism and a rise in professionalized union communications campaigns that privileged paid advertising in commercial media, according to union activists who worked to support the Sasquatch (G. Marsden, personal communication, July 26, 2012; L. Hubich, personal communication, August 15, 2012). In February 2010 the Briarpatch board made the difficult decision to pull the plug on the Sasquatch after just eight issues (S. Stock letter to Sasquatch subscribers, February 16, 2010). While Briarpatch itself survived as a national/international magazine, the experience was a sobering illustration of the necessity and precarity of strong social networks. As observed by Alfonso Gumucio Dagron (2004), maintaining essential relationships is just as important as maintaining a healthy bank balance, if not more so, when it comes to the long-term sustainability of social economy media.

Indeed, today individual donors form the bedrock of the magazine's sustainability, outperforming both magazine sales and advertising revenues:

Our readers are very, very loyal, and I can't overlook the people who provide the five-dollar bill in the mail and say this is the best I can do, and there's [sic] still doing something. And that does amount to a significant amount of money for us. (V. Zink, personal communication, March 27, 2012)

However, the donor culture may be shifting as well. Although the magazine has been gaining younger readers and volunteers, donors tend to be older. "It's a bit concerning when we look through our donor appeals and it's in this impeccable penmanship that you could have only gotten if you went to school in the "30s," noted past editor Valerie Zink (personal communication, March 27, 2012). Indeed, recent census data indicate persons over 75 are far more likely to donate than persons under 35, which Martin Turcotte (2012) postulates could be due to religious influences, greater awareness of the needs beyond family once children gain independence, and, for some, not all, increased income stability. Zink noted there also appears to be a more fundamental cultural shift at play, led by a new generation unaccustomed to passing the plate, paying for written content, or contributing monthly dues to an organization (Zink, personal communication, March 27, 2012). This observation may well turn out to be prescient, particularly as it was offered by someone who was herself a member of the under-30 generation. 


\section{Elliott (2015)}

In an attempt to capture support from its new-generation readership, Briarpatch launched its first online fundraising campaign through the website Indiegogo in July 2014, grossing $\$ 4,055$ in a four-week period, with the net amount still to be determined after free gift subscriptions for donating are fulfilled (Briarpatch, 2014). Comparatively, the traditional fall 2014 mail-out raised approximately $\$ 5,000$ in donations before mailing costs (A. Loewen, personal communication, December 8, 2014). Editor Andrew Loewen said he recognized that online fundraising was important for expanding donor drives to Briarpatch's national and international online readers, who view content for free on the web rather than via paid subscription. At the same time, he noted that web campaigns tend to work only when they focus on short-term projects, instead of core operations. Thus, while online donation drives may offer short-term injections of cash, monthly sustainers and subscribers remain key to budget stability and long-range planning. "For us, it's going to be one more tool in the box ... it's never going to be game-changing," observed Loewen (personal communication, December 8,2014 ).

\section{THEMES}

Reviewing Briarpatch's four-decade history, six major themes emerge regarding media development supports and the struggle for sustainability.

\section{Official media development support is effective}

Government-sponsored media funds significantly contributed to the magazine's development. Both periods of major grant funding coincided with major periods of expansion and professionalization of the magazine. Staff training, improved subscription management, and payment for freelancers were among the benefits experienced.

\section{Media development support generates change}

The ensuing development activities spurred changes in Briarpatch's understanding of its function in the world, and in its relationship with readers. Starting as a hands-on local volunteer activity, the magazine spread its social networks and readership from the streets of Saskatoon to locations throughout the province. In essence, provincial funds helped create a provincial magazine. This change process was mirrored nearly 30 years later with the acquisition of federal funds. Through this process, Briarpatch undertook reader surveys that revealed the breadth of its audience beyond Saskatchewan. In response, Briarpatch began to tailor its content to national and international readers. Just as provincial funding helped create a provincial magazine, federal funding helped create a national magazine. Both of these trends were accompanied by tension between a changing mission and the magazine's relationship to its readers and volunteers.

\section{Government support is attached to competing interests and ideologies}

The Briarpatch case suggests that successful media development strengthens the very things governments seek to avoid-namely, the creation of public platforms for the scrutiny and critique of government policies. After three years of funding, DSS officials were openly disenchanted with the growth their grants had wrought. Federally, through documents obtained through Access to Information, it is apparent that two of three Briarpatch requests between 2008 and 2011 were recommended for approval, but were ultimately rejected by the minister's hand without explanation. Both cuts were sudden, retroactive, and preceded by periods of uncertainty 


\section{Elliott (2015)}

and back-and-forth discussions that absorbed much time and energy among Briarpatch staff, volunteers, and supporters. In this sense, government grants garnered more instability than stability in the long run.

\section{The landscape of non-governmental support has changed}

When provincial funding was withdrawn, Briarpatch was able to survive on the strength of its institutional and social networks. In particular, the labour movement backed the magazine with bulk subscriptions and advertising. By 2008, when the board attempted to launch the Sasquatch, the labour movement had undergone a cultural shift not fully recognized or anticipated by the publication's volunteers and staff. Starting a new publication meant establishing a new relationship in a new era, an era that featured the rise of union communications departments and increased emphasis on controlled messaging through slick in-house publications and paid advertising in the mainstream media. Meanwhile, a landscape of government funding cuts to non-labour groups, including arts groups, environmental NGOs, and development education organizations, left fewer organizations capable of augmenting labour's contributions.

\section{The landscape of reader support is changing}

Whenever Briarpatch experienced financial crisis, its loyal network of donors and subscribers stepped into the breach. Such contributions constitute "the miracle of Briarpatch" that has kept the publication operating for four decades. However, long-term donors and paying subscribers are aging; magazine staff members have initially-not conclusively-observed that the emerging online generation is less likely to proffer tangible, corporeal support to nonprofit organizations, potentially imperiling future fundraising.

\section{Social economy solutions are needed to rebalance the current media ecology}

In the U.S., the potential of nonprofit media to restore public interest journalism has been recognized by two national inquiries: the Knight Commission on the Information Needs of Communities (Knight Commission, 2009); and the Federal Communications Commission (FCC) Working Group on the Information Needs of Communities (Waldman \& WGINC, 2011). Co-operatives UK has also released a report that concludes the marketplace's failure to deliver quality journalism presents a unique social economy opportunity (Boyle, 2012). Indeed, the case of Briarpatch would suggest that the development of a healthy, diverse media ecology requires a reinvigorated civil society investment in non-commercial media. This is not to say Canada's governments should be let off the hook for fulfilling cultural development obligations, particularly in regards to Indigenous media. However, it must be recognized that a precarious and declining funding environment has seriously destabilized Canada's social economy media in recent decades. Civil society organizations that invest their communications budgets primarily in mainstream media advertising need to better recognize the important social role of nonprofit media, as well as the social economy's potential for re-establishing accountable, quality journalism. Non-controlling operational funding-for example, through arms-length foundations and laboursponsored venture capital funds-support for capital equipment purchases, funding pools for investigative journalists, and creative solutions, such as assisting worker takeovers of failed commercial media outlets, are among the types of needed supports identified by practitioners (Elliott, 2015). 


\section{Elliott (2015)}

\section{CONCLUSION}

Briarpatch's fundraising record is an important example of a community-generated solution to the problem of nonprofit media sustainability. Sustaining donor campaigns and subscription sales supported the magazine where official media development assistance failed. A fully reader-supported model allowed the magazine to maintain editorial independence by limiting the influence of funding agencies and advertisers. However, the model has not delivered resources for in-depth journalism to the extent that its publishers desire. As corporate and state media increasingly abandon the field of accountability journalism, this leaves an important question for nonprofit media practitioners and social economy scholars alike to tackle in the coming years: "People want investigative journalism. Do they want to pay for it, how might they pay for it, where will those resources come from?" (V. Zink, personal communication, March 27, 2012). An answer to this question may lie within a social economy that embraces media development as a key undertaking.

\section{REFERENCES}

Baron, D., \& Jackson, P. (1991). Battleground: The socialist assault on Grant Devine's Canadian dream. Toronto, ON: Bedford House.

Bouchard, M.J., Ferraton, C., \& Michaud, V. (2006). Database on social economy organizations: The qualification criteria. Working papers of the Canada research chair on the social economy, research series - no R-2006-03. Montreal, QC: Université du Québec à Montreal.

Boyle, D. (2012). Good news: A co-operative solution to the media crisis. Manchester, UK: Co-operatives UK. URL http://www.uk.coop/resources/good-news-co-operative-solution-media-crisis [November 18, 2015].

Brettle, P. (1979a, April 11). Delayed social services grant precarious for two agencies. Leader-Post, p. 13. URL: http://news.google.com/newspapers?nid=w9EjUEod0xMC\&dat=19790411\&printsec=frontpage \&hl=en [November 18, 2015].

Brettle, P. (1979b, April 19). Loss of provincial funds puts future of Briarpatch in doubt. Leader-Post, p. 18. URL: http://news.google.com/newspapers?nid=w9EjUEod0xMC\&dat=19790419 \&printsec=frontpage\&hl=en [November 18, 2015].

Brettle, P. (1979c, March 7). Province likely to take issue with decision to withdraw social services financing bill. Leader-Post, p. 53. URL: http://news.google.com/newspapers?nid=w9EjUEod0xMC\&dat=19790307 \&printsec=frontpage\&hl=en [November 18, 2015].

Brettle, P. (1979d, March 7). Users of "non-mandated" services could be affected by provincial budget. LeaderPost, p. 53. URL: http://news.google.com/newspapers? nid=w9EjUEod0xMC\&dat=19790307\&printsec =frontpage\&hl=en [November 18, 2015].

Briar Patch Society (1977a, May 3). Grant submission to Frank Bogdasavich, Deputy Minister. Regina, SK: Saskatchewan Dept. of Social Services.

Briar Patch Society. (1977b, May 29). Societies Act annual return. Regina, SK: Saskatchewan Justice, Corporations Branch.

Briarpatch. (2014). Briarpatch magazine: Keep our website going! San Francisco, CA: Indiegogo. URL: https://www.indiegogo.com/projects/briarpatch-magazine-keep-our-website-going [November 18, 2015].

Briarpatch Magazine. (2014). Deeper roots campaign. URL: http://briarpatchmagazine .com/deeper-roots [November 18, 2015]. 


\section{Elliott (2015)}

Canada. Dept. of Canadian Heritage (2004). Canada magazine fund support for business development for small magazine publishers 2003-2004 approved funding. URL: http://www.collectionscanada.gc.ca/webarchives/ 20060129000836/http://www.pch.gc.ca/progs/ac-ca/progs/fcm-cmf/projects2003-2004_e.cfm [accessed November 18, 2015].

Canada. Dept. of Canadian Heritage (2005). Canada magazine fund support for business development for small magazine publishers 2004-2005 approved funding. URL: http:/www.collectionscanada.gc.ca/webarchives/ 20060129000827/http://www.pch.gc.ca/progs/ac-ca/progs/fcm-cmf/projects2004-2005_e.cfm [accessed November 18, 2015].

Canada. Dept. of Canadian Heritage (2006). Canada magazine fund support for business development for small magazine publishers 2005-2006 approved funding. URL: http://www.pch.gc.ca/eng/1289317977865/ 1289317977867 [December 7, 2015].

Canada. Dept. of Canadian Heritage (2007). Canada magazine fund support for business development for small magazine publishers 2006-2007 approved funding. URL: http: //www.pch.gc.ca/eng/1289317977865/ 1289317977867 [December 7, 2015].

Canada. Dept. of Canadian Heritage (2008). Canada magazine fund support for business development for small magazine publishers 2007-2008 approved funding. URL: http:// www.pch.gc.ca/eng/1289317977865/ 1289317977867 [December 7, 2015].

Canada. Dept. of Canadian Heritage (2009). Canada magazine fund support for business development for small magazine publishers 2008-2009 approved funding. URL: http:// www.pch.gc.ca/eng/1289317977865/ 1289317977867 [December 7, 2015].

Canadian Council for International Co-operation. (1995). Canada's voluntary sector in international development. Ottawa, ON: CCIC. URL: http://www.ccic.cal_files/en/archives/voluntary_sector_ canada_vs_in_international_development_1995_12.pdf [November 18, 2015].

Collier, K. (1993, July-August). How Briarpatch got its name. Briarpatch, 22(6), 9.

Community Media Forum Europe (2012). Community media in Europe: First country ranking. URL: http://cmfe .eu/? $\mathrm{p}=864$ [November 18, 2015].

Elliott, P.W. (2015). Independent voices: Third sector media development and local governance in Saskatchewan [PhD dissertation]. Saskatoon, SK: University of Saskatchewan. URL: http://ecommons .usask.ca/handle/10388/ETD-2015-03-2010 [November 18, 2015].

Fischer, M. (1993, July-August). Looking back. Briarpatch, 22(6), 10.

Gilmour, M. (1979, March 21). Briarpatch staff: "Compelled to set the record straight." The Commonwealth.

Gilmour, M. (1993, July-August). The good ol' days. Briarpatch, 22(6), 13-14.

Gumucio Dagron, A. (2004). The long and winding road of alternative media. In J.D.H. Downing and D. Mcquail (Eds.), The SAGE handbook of media studies (pp. 41-66). Thousand Oaks, CA: SAGE.

Hackett, R.A., \& Carroll, W.A. (2004). Critical social movements and media reform. Media Development, 51(1), 14.

Karikari, K. (2000). The development of community media in English-speaking West Africa. In K. Baofo (Ed.), Promoting community media in Africa (pp. 43-60). Paris, FR: UNESCO.

Karst, G. (1977). Report on The Briar Patch history and functions [practicum report, Social Work 448]. Regina, SK: University of Regina. 


\section{Elliott (2015)}

Knight Commission on the Information Needs of Communities. (2009). Informing communities: Sustaining democracy in the digital age. Washington, DC: The Aspen Institute. URL: http://www.knightcomm .org/read-the-report-and-comment/ [November 18, 2015].

Leader-Post. (1981, June 8). Typsetting business helps brighten magazine's finances. Leader-Post, p. A4. URL: http://news.google.com/newspapers?nid=w9EjUEod0xMC \&dat=19810608 \&printsec=frontpage\&hl=en [November 18, 2015].

Manz, G. (1993, July-August). Life at Briarpath. Briarpatch, 22(6), 47-48.

Moulaert, F., \& Ailenei, O. (2005). Social economy, third sector and solidarity relations: A conceptual synthesis from history to present. Urban Studies, 42(11), 2037-2053.

Murillo, M. (2010). Indigenous community radio and the struggle for social justice in Columbia. In K. Howley (Ed.), Understanding community media (pp. 240-249). Thousand Oaks, CA: SAGE.

Myers, M. (2011). Voices from the villages: Community radio in the developing world. Washington, DC: Center for International Media Assistance. URL: http://www .cima.ned.org/resource/voices-from-villagescommunity-radio-in-the-developing-world/ [November 18, 2015].

Paavo, A. (1993, July-August). The rock and the pig. Briarpatch, 22(6), 18-20.

Potruff, N. (1975, May). Report from the Briar Patch meeting. The Briar Patch, (23), 1.

Powell, C. (1993, July-August). Raising hell. Briarpatch, 22(6), 15-16.

Reiter, R.J. (1975, Sept. 26). Letter of reference to funding agencies re: Briarpatch. Estevan Sub-Office, Saskatoon, SK: Dept. of Social Services.

Restakis, J. (2006). Defining the social economy: The B.C. context. Prepared for the B.C. Social Economy Roundtable. Vancouver, BC: British Columbia Co-operative Association.

Robertson, L. (1979, March 7). Tangle of motives background to prickly question of Briarpatch grant. The Commonwealth.

Robertson, L. (1993, July-August). The Briarpatch transition. Briarpatch, 22(6), 11-12.

Rolfes, H.H. (1976, April 26). Grant approval letter. Minister of Social Services to Maria Fisher, Briar Patch Society.

Saskatchewan. Dept. of Social Services (1977). Administrative terms of reference between the Minister of Social Services and Briar Patch Society.

Smillie, B. (1993, July-August). Life at the top. Briarpatch, 22(6), 17.

Turcotte, M. (2012). Charitable giving by Canadians. Canadian social trends series. Ottawa, ON: Statistics Canada.

Waldman, S. \& The Working Group on the Information Needs of Communities (WGINC). (2011). The information needs of communities: The changing media landscape in a broadband age. Washington, DC: U.S. Federal Communications Commission. URL: https://transition.fcc.gov/osp/inc-report/The_ Information_Needs_of_Communities.pdf [November 18, 2015].

Warnock, J. (1993, July-August). The future of coalitions. Briarpatch, 22(6), 39-41.

\section{ABOUT THE AUTHOR / L'AUTEUR}

Patricia W. Elliott is Assistant Professor of journalism at the University of Regina. Email: patricia.elliott@uregina.ca . Website: www.patriciaelliott.ca 